\title{
ANTIGENIC TYPING OF BRAZILIAN RABIES VIRUS SAMPLES ISOLATED FROM ANIMALS AND HUMANS, 1989-2000
}

\author{
Silvana Regina FAVORETTO(1), Maria Luiza CARRIERI(1), Elenice Maria S. CUNHA(2), Elizabeth A.C. AGUIAR(3), Luzia Helena Q. SILVA(4), Miriam M. SODRÉ(3),
} Maria Conceição A.M. SOUZA(2) \& Ivanete KOTAIT(1)

\begin{abstract}
SUMMARY
Animal and human rabies samples isolated between 1989 and 2000 were typified by means of a monoclonal antibody panel against the viral nucleoprotein. The panel had been previously established to study the molecular epidemiology of rabies virus in the Americas. Samples were isolated in the Diagnostic Laboratory of the Pasteur Institute and in other rabies diagnostic centers in Brazil. In addition to the fixed virus samples CVS-31/96-IP, preserved in mouse brain, and PV-BHK/97, preserved in cell culture, a total of 330 rabies virus samples were isolated from dogs, cats, cattle, horses, bats, sheep, goat, swine, foxes, marmosets, coati and humans. Six antigenic variants that were compatible with the pre-established monoclonal antibodies panel were defined: numbers 2 (dog), 3 (Desmodus rotundus), 4 (Tadarida brasiliensis), 5 (vampire bat from Venezuela), 6 (Lasiurus cinereus) and Lab (reacted to all used antibodies). Six unknown profiles, not compatible with the panel, were also found. Samples isolated from insectivore bats showed the greatest variability and the most commonly isolated variant was variant-3 (Desmodus rotundus). These findings may be related to the existence of multiple independent transmission cycles, involving different bat species.
\end{abstract}

KEYWORDS: Rabies; Monoclonal antibodies; Antigenic typing; Brazil.

\section{INTRODUCTION}

Considerable progress has been achieved in rabies prophylaxis in Brazil, mainly in the state of São Paulo where urban rabies, characteristic of dogs and cats, showed a marked decrease and practically disappeared. While 169 cases were identified in 1995; 104 in 1996; 11 in 1997; 7 in 1998; 5 in 1999 only 4 cases were found in 2000. The same occurrence has been observed in other Brazilian states. These results were followed by a lower incidence of human rabies in Brazil, with a reduction from 73 cases in 1990 to 26 cases in $2000^{\circ}$. On the other hand, a gradual increase in the number of rabies cases in herbivores, transmitted by Desmodus rotundus, was observed. Rabies virus were not only isolated from vampire bats but also from several non-vampire bat species in rural and urban areas, respectively.

Rabies epidemiological studies presented a major advance since the 80 's, after monoclonal antibodies in antigenic analyses became available. Monoclonal antibodies produced through the immunization of BALB/c mice by the inactivated rabies vaccine, and the indirect immunofluorescence technique with monoclonal antibodies, established by WIKTOR \& KOPROWSKI $(1978)^{17}$, have greatly contributed to epidemiological studies. It became possible to define time and geographic distribution of samples, and the species acting as rabies virus reservoirs.
In recent years, several researchers conducted epidemiological studies in the Americas and the Caribbean, using monoclonal antibodies techniques ${ }^{1,2,7,10,12,16}$. Antigenic and immunogenic studies using monoclonal antibodies with rabies virus strains isolated in Brazil were carried out by GERMANO et al., HAYASHI et al. and ROEHE et al. ${ }^{4,5,10}$. In 1994, SACRAMENTO et al. ${ }^{11}$, used RT-PCR and genotype sequencing to study samples from the state of São Paulo, and found distinctive differences among them.

In 1996, Pasteur Institute of São Paulo implemented an indirect immunofluorescence technique, using a panel of monoclonal antibodies against the viral nucleoprotein, produced by the Centers for Disease Control and Prevention (CDC), Atlanta, GA, United States, and defined by the Pan American Health Organization (PAHO). The objective was to study the antigenic typing of samples isolated in the Americas?.

The objetive of this work is to study the antigenic variants from samples isolated between 1989 and 2000 in different Brazilian regions from several species. Another objective was to identify the infection source in cases that did not offer sufficient epidemiological information. The samples were studied in the laboratory of the Pasteur Institute of São Paulo, between September 1996 and December 2000.

Study carried out in the Diagnostic Laboratories of the Pasteur Institute of São Paulo.

(1) Instituto Pasteur. Avenida Paulista 393, 01311-000 São Paulo, SP, Brazil.

(2) Instituto Biológico. Av. Conselheiro Rodrigues Alves 1252, 04014-000 São Paulo, SP, Brazil

(3) Centro de Controle de Zoonoses. Rua Santa Eulália 86, 02031-020 São Paulo, SP, Brazil

(4) Curso de Medicina Veterinária, UNESP Araçatuba. Rua Clóvis Pestana 793, 16050-680 Araçatuba, SP, Brazil

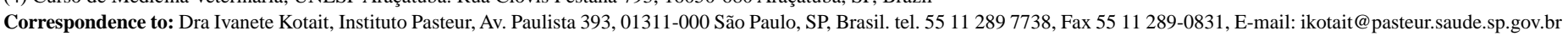




\section{MATERIAL AND METHODS}

STUDY AREAS: 330 samples were included in the study, most of them from the state of São Paulo (208 samples), while the remainder came from other states (122 samples).

SAMPLES: In addition to the CVS 31/96-IP fixed virus strain sample, kept in brain of suckling mice, and to the PV BHK/97-IP strain, maintained in cell culture, street rabies virus were analyzed. Samples for this study comprized 98 dog samples; 13 cat samples; 34 cattle samples; 21 horse samples; 116 chiroptera; 36 human samples; 5 sheep samples; 1 goat sample; 2 swine samples; one fox sample (unknown species); 1 marmoset (Callithrix jacchus) sample; 1 coati (Nasua nasua) and 1 little fox (Cerdocyon thous) sample.

In the first phase of the study, the following samples were processed: different species samples isolated in one same region, samples from different regions, and sometimes from the same region at different times. Subsequently, rabies virus isolated from wild animals, humans or cases with an epidemiological history to be clarified were granted priority.

All samples were passed once through the intracerebral route in albino-Swiss recently weaned mice, whose weight ranged between 12 to $14 \mathrm{~g}$, produced and maintained in controlled environment cages at the Pasteur Institute. Central nervous system samples for the immunofluorescence slides were collected after mice euthanasia during the paralytic phase of the disease. Samples were immediately processed.

MONOCLONAL ANTIBODIES: An 8 monoclonal-antibody panel against rabies nucleoprotein, produced by the Centers for Disease Control and Prevention (CDC), Atlanta, GA, United States ${ }^{2}$, for the typification of strains found in the Americas ${ }^{9}$ was used.

Each sample was processed with the monoclonal antibodies panel at least twice, in different batches and on different days, to determine the reproducibility of the test. Samples that showed different profiles from the expected standard, not compatible with those determined in the panel, were processed several times and in duplicate, or with monoclonal antibodies in different dilutions.

INDIRECT IMMUNOFLUORESCENCE TECHNIQUE: Reaction patterns to the monoclonal antibody panel were determined by the indirect immunofluorescence technique performed according to DIAZ et al. ${ }^{2}$. Briefly, slides with imprint of central nervous system tissue from infected mice with wild rabies virus samples and standard samples were prepared. Slides were fixed overnight in acetone at $-20{ }^{\circ} \mathrm{C}$. Eight monoclonal antibodies were added in pre-established dilutions and incubated at $37^{\circ} \mathrm{C}$ for 30 minutes.

After each reaction the slides were individually washed with PBS and fluorescent anti-mouse polyvalent conjugate (SIGMA ${ }^{\mathrm{R}}$ - USA) was added to the slides and those were incubated at $37^{\circ} \mathrm{C}$ for 30 minutes.

After two washings with PBS and a final washing with distilled water, the slides were ready for readings in the fluorescence microscope.

All samples from the first passage on mice were previously submitted to a direct immunofluorescence test and only samples with infection rates higher than $80 \%$ of the observed fields were typified.

Based on the presence of fluorescence, reactions were classified as intense or non-reactive. Some weak reactions were observed, which were mostly considered as either negative or tested again with a different dilution of the monoclonal antibodies.

\section{RESULTS}

Six antigenic variants were found, as defined in the monoclonal antibody panel, and were compatible with variants number 2, 3, 4, 5, 6 and Lab. These results are shown in Table 1.

Table 1

Antigenic characterization of rabies virus isolates in Brazil, using a panel monoclonal antibodies

\begin{tabular}{|c|c|c|c|}
\hline \multirow[b]{2}{*}{ Host } & \multicolumn{2}{|c|}{ Cases } & \multirow[b]{2}{*}{ Antigenic variant $(\mathrm{AgV})$} \\
\hline & No./Total & $\%$ & \\
\hline Dog & $86 / 98$ & 87.8 & $2-$ Dog \\
\hline Dog & $12 / 98$ & 12.2 & 3 - Desmodus rotundus \\
\hline Cat & $8 / 13$ & 61.5 & $2-$ Dog \\
\hline Cat & $4 / 14$ & 30.8 & $3-D$. rotundus \\
\hline Cat & $1 / 13$ & 7.7 & 5 - Vampire bat from Venezuela \\
\hline Cattle & $34 / 34$ & 100.0 & $3-D$. rotundus \\
\hline Horse & $21 / 21$ & 100.0 & $3-D$. rotundus \\
\hline Bat & $93 / 116$ & 80.2 & $3-D$. rotundus \\
\hline Bat & $10 / 116$ & 8.6 & 4 - Tadarida brasiliensis \\
\hline Bat & $3 / 116$ & 2.6 & 5 - Vampire bat from Venezuela \\
\hline Bat & $2 / 116$ & 1.7 & 6 - Lasiurus cinereus \\
\hline Bat & $8 / 116$ & 6.9 & $*$ \\
\hline Human & $28 / 36$ & 77.8 & $2-$ Dog \\
\hline Human & $3 / 36$ & 8.3 & 3 -Desmodus rotundus \\
\hline Human & $3 / 36$ & 8.3 & $\mathrm{Lab}^{* *}$ \\
\hline Human & $2 / 36$ & 5.5 & $*$ \\
\hline Goat & $1 / 1$ & 100.0 & $3-D$. rotundus \\
\hline Sheep & $4 / 5$ & 80.0 & $3-D$. rotundus \\
\hline Sheep & $1 / 5$ & 20.0 & $2-\operatorname{Dog}$ \\
\hline Swine & $2 / 2$ & 100.0 & $3-D$. rotundus \\
\hline Coati & $1 / 1$ & 100.0 & $\mathrm{Lab}^{* *}$ \\
\hline Fox & $1 / 1$ & 100.0 & $2-\operatorname{Dog}$ \\
\hline Little fox & $1 / 1$ & 100.0 & 5 - Vampire bat from Venezuela \\
\hline Marmoset & $1 / 1$ & 100.0 & $*$ \\
\hline PV-BHK/97-IP & $1 / 1$ & 100.0 & $\mathrm{Lab}^{* *}$ \\
\hline CVS-31/96-IP & $1 / 1$ & 100.0 & $\mathrm{Lab}^{* *}$ \\
\hline
\end{tabular}

*antigenic type not determined; **compatible with the profile established for laboratory strains.

Six different profiles that were not compatible with those in the panel were also identified: four in non-vampire bats and one in humans and other in marmoset. Variant 5, virus also found in non-vampire bats, as well as in one cat and a little fox (Cerdocyon thous) from São Paulo (Table 2). 
Table 2

Reaction patterns of Brazilian rabies virus isolates to monoclonal antibodies of possible different antigenic variants

\begin{tabular}{|c|c|c|c|c|c|c|c|c|c|}
\hline $\begin{array}{l}\text { Identification/ } \\
\text { Year of isolation }\end{array}$ & Host & $\mathrm{C} 1$ & $\mathrm{C} 4$ & C9 & $\mathrm{C} 10$ & $\mathrm{C} 12$ & $\mathrm{C} 15$ & $\mathrm{C} 18$ & C19 \\
\hline 096.M/96 & Histiotus velatus & - & - & - & - & + & - & - & - \\
\hline 4887-M/99 & H. velatus & - & - & - & - & + & - & - & - \\
\hline $545-\mathrm{M} / 95$ & Lasiurus borealis & - & + & + & + & - & - & - & - \\
\hline 549IB/99 & Myotis albecens & - & + & + & + & - & - & - & - \\
\hline 705-M/97 & Nyctinomops macrotis & - & + & - & + & + & - & + & + \\
\hline 3085-M/97 & N. laticaudatus & - & + & - & + & + & - & + & + \\
\hline $205 \mathrm{IB} / 98$ & N. laticaudatus & - & + & - & + & - & - & - & + \\
\hline 055IB/99 & N. laticaudatus & - & + & - & + & - & - & - & + \\
\hline 034IB/98 & Eptesicus furinalis & - & + & - & + & + & - & - & - \\
\hline $1031 \mathrm{IB} / 98$ & Eumops auripendulus & - & + & - & + & + & - & - & - \\
\hline 969-M/00 & E. furinalis & - & + & - & + & + & - & - & - \\
\hline 004-M/96 & Cat & - & + & - & + & + & - & - & - \\
\hline $5911-\mathrm{M} / 00$ & Cerdocyon thous & - & + & - & + & + & - & - & - \\
\hline 2079-M/98 & Human & - & - & + & + & - & - & - & - \\
\hline 4497-M/98 & Human & - & - & + & + & - & - & - & - \\
\hline 4108-M/98 & Callithrix jacchus & - & - & + & + & - & - & - & - \\
\hline
\end{tabular}

- Negative; + positive.

Variant 3 characteristic of vampire bats, was isolated from most of the studied animal species (Table 3), showing the importance of Desmodus rotundus as reservoir of rabies virus in Brazil.

Table 4 shows the occurrence of more than one antigenic variant, variants 2 and 3, circulating simultaneously in a rabies outbreak in the state of São Paulo and the importance of antigenic studies in the identification and differentiation of multiple viral antigens.

\section{DISCUSSION}

From the 98 samples isolated from dogs, 86 (87.8\%) were compatible with panel variant 2 , which is characteristic of dog isolates. When DIAZ et al. ${ }^{2}$ studied different samples from Latin America and the Caribbean in 1994, they had already found only variant 2 in dogs from Brazil, as opposed to other countries, where isolate variants 1 and 2 were found in $\operatorname{dogs}^{2}$. In 12 samples (12.2\%), however, variant 3, which is characteristic of isolates from Desmodus rotundus, was identified in large and small cities in the states of São Paulo and Pará, from 1998-2000. This finding had already been reported by DIAZ et al. ${ }^{2}$ in dogs from Central America. Six of the twelve cases were isolated episodes, from municipalities where urban rabies cases had not been detected for many years, but had had an herbivore rabies epidemic in surrounding areas. The finding of a vampire bat strain in dogs confirms their importance as a rabies virus reservoir, transmitting rabies to animals in rural and urban areas, making the reintroduction of urban rabies possible even in cities where the disease is under control.

In 13 samples isolated from cats, 8 cases $(61.5 \%)$ of variant 2 profile characteristic of dogs were found; 4 cases $(30.8 \%$ ) of variant 3 (Desmodus rotundus) and one $(7.7 \%)$ of variant 5 (vampire bat from Venezuela) were also found. In cases where variant 3 was identified, samples came from regions where rabies had been under control in pets (dogs and cats) for over 10 years. Variant 5 was identified in only 1 case. It should be noted, however, that weak reactions to antibodies in the pre-established panel were considered to be negative.

Table 3

Antigenic variant 3 - Desmodus rotundus - isolated from different animal species, 1989 to 2000

\begin{tabular}{lcr}
\hline Host & Strains quantity/Total & $\%$ \\
\hline Dog & $12 / 98$ & 12.2 \\
Cat & $4 / 13$ & 30.8 \\
Cattle & $34 / 34$ & 100.0 \\
Horses & $21 / 21$ & 100.0 \\
Vampire Bat & $56 / 56$ & 100.0 \\
Non vampire Bat & $35 / 60$ & 58.3 \\
Human & $3 / 36$ & 8.3 \\
Goat & $1 / 1$ & 100.0 \\
Sheep & $4 / 5$ & 80.0 \\
Swine & $2 / 2$ & 100.0 \\
\hline
\end{tabular}

Table 4

Antigenic variants of rabies virus isolated from animals and humans from Ribeirão Preto city in the state of São Paulo, 1995 to 1998, to show simultaneous circulation of more than one antigenic variant

\begin{tabular}{ccc}
\hline Identification/Year of isolation & Host & Antigenic Variant \\
\hline $0006-\mathrm{V} / 95$ & Human & 2 \\
$0800-\mathrm{M} / 95$ & Canine & 2 \\
$0957-\mathrm{M} / 95$ & Bat & 3 \\
$1367-\mathrm{M} / 95$ & Feline & 2 \\
$2763-\mathrm{M} / 95$ & Canine & 2 \\
$1738-\mathrm{M} / 96$ & Feline & 2 \\
$0260-\mathrm{M} / 98$ & Canine & 3 \\
\hline
\end{tabular}




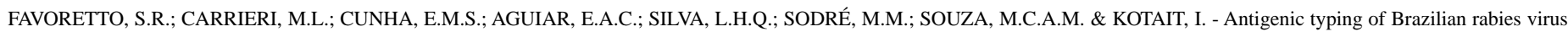
samples isolated from animals and humans, 1989-2000. Rev. Inst. Med. trop. S. Paulo, 44(2):91-95, 2002.

Variant 3 was always identified as the isolated strain in cattle, horses, goat and swine samples, regardless of the Brazilian region or the region in the state of São Paulo from which they came. Variant 2, however, was identified in one of the 5 sheep samples studied, confirming the importance of dogs in the transmission of rabies to herbivores, especially in regions where canine rabies epidemics do occur.

In 1996, ROEHE et al..$^{10}$ studied 14 samples isolated in cattle and horses using another monoclonal panel, reporting the differences between these strains and those isolated from other species.

SACRAMENTO et al. ${ }^{11}$ verified two biotypes in the state of São Paulo: one from urban domestic animals, quite similar to fixed viruses CVS, PV, PM etc.; and another from cattle, horses and chiropters with marked differences when compared to fixed viruses.

In 2001, ITO et al. $^{6}$ analyzed 50 rabies virus samples isolated in Brazil and showed these belonged to genotype 1 and were clustered into two reservoir groups: dogs and vampire bats which are maintained independently.

Of the 36 strains isolated in humans, 28 samples (78.8\%) were characterized as variant 2, confirming that dogs are the main transmitters of human rabies. Variant 3 was identified in 3 cases (8.3\%). In another 3 cases from Northeastern Brazilian states, a variant compatible with the profile of fixed virus strains which reacted to all antibodies was characterized, and the epidemiological data suggesting the dog as the aggressor. This same profile was also observed later in a wild terrestrial animal from the same region.

In another two cases of human samples, no compatibility existed between isolated strains and those proposed in the panel, although there were similarities between their profiles. The epidemiological study of samples from the state of Ceará, in Northeastern Brazil, suggested aggression by a marmoset, a common wild animal of the region. These results were confirmed by genetic studies (FAVORETTO et al., 2001).

The highest variability, however, was presented in the study of the 116 strains isolated from bats: variant $3(80.2 \%)$ was identified in 93 samples, variant $4(8.6 \%)$ in 10 ; variant $5(2.6 \%)$ in 3 ; variant $6(1.7 \%)$ in 2 . In 8 samples, all from non-vampire bats, the isolated variant was not compatible with the profiles defined in the panel. It should be noted that variant 3 was always identified in vampire bat samples, similar to what was found by DIAZ et al. and DELPIETRO et al. ${ }^{1,2}$. On the other hand, variants 4, 5 and 6 were identified in samples isolated from nonvampire bats, as well as others that did not belong to the panel. This finding confirms the results obtained by DELPIETRO et al. (1997) ${ }^{1}$, who had already identified frugivorous bats (Artibeus lituratus), from Brazil and Argentina, with variant 3, although DIAZ et al. $(1994)^{2}$ had previously described only variant 3 in vampire bats and their victims. The fact that variant 3 was identified in non- vampire bats suggests a possible relationship among vampire species, an observation warranting further study. Special attention should be given in determining the significance of these animals in maintaining the rabies virus in terrestrial species (SMITH, 1988) ${ }^{12}$.

Among the variants not identified in the panel, the same profile was found in samples of chiropters from different cities in the state of São
Paulo, as: in 1997, in strains isolated from Nictinomops laticaudatus in cities near the southern coast of São Paulo; in samples of Lasiurus borealis and Myotis albecens from different sites, far from each other; and in samples of Eptesicus furinalis, Eptesicus diminutus and Eumops auripendulus in cities in close proximity in the Northern part of São Paulo.

Other different profiles were observed in two samples from the same region of São Paulo which were isolated from Histiotus velatus, in 1996 and 1999. Another variant was isolated from two samples of Nictinomops laticaudatus in 1998 and 1999. Genetic analyses may confirm the existence of new variants.

Results presented in Table 3 show the importance of Desmodus rotundus in transmitting the rabies virus to various terrestrial and nonterrestrial species. These data suggest that it is the main reservoir of the rabies virus in our environment.

Table 4 shows an outbreak of canine rabies, in Ribeirão Preto (a large city in the Northern part of São Paulo State), where variants 2 and 3 will be identified concurrently in dogs, in agreement with the results of ITO et al. ${ }^{6}$.

Using protection tests in mice vaccinated with modified suckling mouse brains (SMB), HAYASHI et al. $(1984)^{5}$ and ZANETTI et al. $(1998)^{18}$ showed that these vaccines provides different degrees of protection against wild rabies viruses.

These preliminary studies using the monoclonal antibody technique are also important in selecting strains to be used in immune assays, that will evaluate the real protection provided by fixed virus vaccines when challenged by street virus, especially those characterized as new variants (SUREAU et al., 1983) ${ }^{15}$.

\section{RESUMO}

\section{Tipificação antigênica de amostras brasileiras de vírus rábico isoladas de animais e humanos, no período de 1989 a 2000}

Amostras de vírus rábico isoladas de animais e humanos no período de 1989 a 2000 foram tipificadas antigenicamente com a utilização de um painel de anticorpos monoclonais contra a nucleoproteína viral, préestabelecido para o estudo da epidemiologia molecular do vírus rábico isolado nas Américas. As amostras testadas foram isoladas no laboratório de diagnóstico do Instituto Pasteur e outros centros de diagnóstico de raiva no Brasil. Além das cepas de vírus rábico fixo CVS-31/96-IP, mantida em cérebro de camundongos e a PV-BHK/97, mantida em cultura de células, cepas de vírus rábico isoladas de cães, gatos, bovinos, eqüinos, morcegos, ovinos, caprino, suínos, raposa, sagüí, coatí, guaxinim e humanos, totalizaram 330 amostras. Seis variantes antigênicas foram definidas, compatíveis com perfís observados no painel de anticorpos monoclonais pré-estabelecido utilizado, as de número 2 (cão), 3 (Desmodus rotundus), 4 (Tadarida brasiliensis), 5 (Vampiro da Venezuela), 6 (Lasiurus cinereus) e Lab (reagente a todos os anticorpos utilizados), além de outros seis perfís desconhecidos, não compatíveis com aqueles observados no painel utilizado. A maior variabilidade foi observada entre as amostras isoladas de morcegos insetívoros e a variante mais comum isolada entre as espécies foi a variante 3 (Desmodus 
rotundus). Estes fatos podem representar a existência de múltiplos ciclos de transmissão independentes, envolvendo diferentes espécies de morcegos.

\section{ACKNOWLEDGEMENTS}

The authors wish to thank professionals from different states of Brazil who sent samples to Pasteur Institute.

\section{REFERENCES}

1. DELPIETRO, H.A.; GURY-DHOMEN, F.; LARGHI, O.P.; MENA-SEGURA, C. \& ABRAMO, L. - Monoclonal antibody characterization of rabies virus strains isolated in the River Plate Basin. Zbl. Vet.-Med., 44: 477-483, 1997.

2. DIAZ, A.M.; PAPO, S.; RODRIGUEZ, A. \& SMITH, J.S. - Antigenic analysis of rabiesvirus isolates from Latin America and the Caribbean. Zbl. Vet.-Med., 41: 153-160, 1994

3. FAVORETTO, S.R.; DE MATTOS, C.C.; MORAIS, N.B.; ARAÚJO, F.A.A. \& DE MATTOS, C.A. - Rabies in marmosets (Callithrix jacchus), Ceará, Brazil. Emerg. infect. Dis., 7: 1062-1065, 2001.

4. GERMANO, P.M.L.; SILVA, E.V.; MIGUEL, O. \& SUREAU, P. - Variantes antigenicas del virus de la rabia aisladas en el nordeste y sudeste del Brasil. Estudio preliminar. Bol. Ofic. sanit. panamer., 108: 39-45, 1990.

5. HAYASHI, Y.; MORA, E.; CHANDELIER, E.L.; MONTANO, J.A. \& OHI, M. - Estudos de proteção cruzada de 24 cepas de virus rábico isoladas de diferentes espécimes animais no Brasil. Arq. Biol. Tecnol., 27: 27-35, 1984.

6. ITO, M.; ARAI, Y.T.; ITOU, T.; SAKAI, T. et al. - Genetic characterization and geographic distribution of rabies viruses isolates in Brazil: identification of two reservoirs, dogs and vampire bats. Virology, 284: 214-222, 2001.

7. LARGHI, O.P.; DELPIETRO, H.A.; MALAGA-ALBA, A.; SMITH, J.S. \& WIKTOR, T.J. - Monoclonal antibody studies of rabies virus isolated from Argentina and Peru, South America. In: TRAENHART, O.; KOPROWSKY, H.; BOGEL, K. \& SUREAU, P., ed. Progress in rabies control. Kent, Wells Medical Limited, 1989.
8. MINISTÉRIO DA SAÚDE. Fundação Nacional de Saúde. Centro Nacional de Epidemiologia. Coordenação Geral de Vigilância Epidemiológica. Coordenação de Doenças Transmitidas por Vetores e Antropozoonoses - Relatório Técnico, 2000. Brasília, FNS, 2000

9. PANAMERICAN HEALTH ORGANIZATION - PAHO Expert consultation on the technical bases for recognition of rabies-free areas and animal quarantine requirements. Final report. Santo Domingo, Dominican Republic, 21-22 November 1994. p. 1-8.

10. ROEHE, P.M.; PANTOJA, L.D.; SHAEFER, R.; NARDI, N.B. \& KING, A.A. - Analysis of Brazilian rabies virus isolated with monoclonal antibodies to Lyssavirus antigens. Rev. Microbiol. (S. Paulo), 28: 288-292, 1997.

11. SACRAMENTO, D.R.V.; TORDO, N. \& KOTAIT, I. - Estudo molecular do vírus da raiva isolado no Estado de São Paulo. In: REUNIÃO ANUAL DO INSTITUTO BIOLÓGICO, 7., São Paulo, 1994. Anais. p. 15. r. 029

12. SMITH, J.S. - Monoclonal antibody studies of rabies in insectivorous bats of the United States. Rev. infect. Dis., 10(suppl. 4): S637-S643, 1988.

13. SMITH, J.S. - Rabies virus epitopic variation: use in ecologic studies. Advanc. Virus Res., 36: 215-253, 1989

14. SMITH, J.S.; REID-SANDEN, F.L.; ROUMILLAT, L.F. et al. - Demonstration of antigen variation among rabies virus isolates by using monoclonal antibodies to nucleocapsid proteins. J. clin. Microbiol., 24: 573-580, 1986.

15. SUREAU, P.; ROLLIN, P. \& WIKTOR, T.J. - Epidemiologic analysis of antigen variations of street rabies virus: detection by monoclonal antibodies. Amer. J. Epidem., 117: 605-609, 1983.

16. WIKTOR, T.J. \& KOPROWSKI, H. - Antigenic variants of rabies virus. J. exp. Med., 152: $99-112,1980$.

17. WIKTOR, T.J. \& KOPROWSKI, H. - Monoclonal antibodies against rabies virus produced by somatic cell hybridization: detection of antigen variants. Proc. nat. Acad. Sci. (Wash.), 75: 3938-3942, 1978

18. ZANETTI, C.R.; FRANCO, M.T.; VASSÃO, R.C.; PEREIRA, C.A. \& PEREIRA, O.A - Failure of protection induced by a Brazilian vaccine against Brazilian wild rabies viruses. Arch. Virol., 143: 1745-1756, 1998.

Received: 24 August 2001 Accepted: 03 April 2002 